\title{
ANALISIS PENGGUNAAN E-LEARNING MADRASAH SEBAGAI MEDIA PEMBELAJARAN BAHASA ARAB DI MTsN 2 KOTA SURABAYA DI ERA PANDEMI COVID-19
}

\author{
Hamdatul Musyarrofah ${ }^{1}$, Hilma Nailis Syarifiyah ${ }^{2}$, \\ Muhammad Anis Bachtiar ${ }^{3}$ \\ ${ }^{1}$ Pendidikan Bahasa Inggris Universitas Islam Negeri Sunan Ampel Surabaya, Indonesia \\ 2 Pendidikan Bahasa Arab Universitas Islam Negeri Sunan Ampel Surabaya, Indonesia \\ ${ }^{3}$ Universitas Islam Negeri Sunan Ampel Surabaya, Indonesia \\ Email: hamdatul.musyarrofah732@gmail.com ${ }^{1}$, hilmanailis@gmail.com², anis.bachtiar@uinsby.ac.id ${ }^{3}$
}

\begin{tabular}{l|l|l} 
Received: Agustus 2021 & Accepted: Desember 2021 & Published: Desember 2021 \\
\hline
\end{tabular}

\begin{abstract}
The implementation of 4C (Critical Thinking, Communication, Collaboration, Creativity) in the learning process is vital in order to prepare students for the 21st century (Supriano, 2019). In this era which the learning process conducts online, the teachers may still emphasize those values through kinds of questions served especially through e-learning madrasah. Thus, the objectives of this study are to be a reference for the other teachers by exploring the kinds of questions in learning Arabic, also give suggestions or even convey to certain parts so that a revision of e-learning madrasah will be conducted by analyzing the obstacles. Applying descriptive qualitative method, the researchers assume that through the futures of e-learning madrasah the teachers provide $P P T / P D F$, multiple choices, short answer and essay questions for maharah qira'ah (reading skill), listening to a video/audio for maharah istima' wa kalam (listening and speaking skills), fill-in-theblank, short answer questions as well as asking students to create a simple essay for maharah kitabah (writing skill). Nevertheless, the Arabic font in e-learning madrasah and the learning schedule which is not specific and fixed become the obstacles.
\end{abstract}

Keywords: e-learning madrasah, kinds of questions, obstacles of online Arabic learning

\begin{abstract}
Abstrak: Penerapan 4C (Critical Thinking, Communication, Collaboration, Creativity) dalam pembelajaran sangatlah penting guna mempersiapkan peserta didik menghadapi abad 21. Masa di mana pembelajaran dilakukan daring, bukan tidak mungkin bagi guru untuk tetap menekankan nilai-nilai tersebut melalui model soal yang disajikan khususnya dalam e-learning madrasah. Sehingga tujuan penelitian ini yaitu menjadi referensi untuk guru lainnya dengan dieksplornya model soal dalam pembelajaran bahasa Arab ini. Juga dengan menganalisis kendala yang ada, peneliti berharap dapat memberikan saran atau bahkan membantu menyampaikan agar diadakan perbaikan dalam fitur e-learning madrasah. Dengan menerapkan metode kualitatif deskriptif, peneliti menyimpulkan bahwa dengan fitur e-learning guru menyajikan PPT/PDF, soal pilihan ganda, isian, dan essay untuk maharah qira'ah (keterampilan membaca), mendengarkan membuat video/audio untuk maharah istima' wa kalam (keterampilan menyimak dan berbicara), fill-in-the-blank, isian, essay dan membuat karangan tulis sederhana untuk maharah kitabah (keterampilan menulis). Adapun font Arab dalam e-learning madrasah serta jadwal pembelajaran tidak pasti dan spesifik menjadi kendala.
\end{abstract}

Kata Kunci: e-learning madrasah, model soal, kendala pembelajaran bahasa Arab online 


\section{A. Pendahuluan}

Hampir seluruh negara di dunia termasuk Indonesia terkena dampak dari adanya wabah virus corona atau covid-19 yang tentunya juga tidak bisa kita hindari, hal tersebut sangat berpengaruh terhadap semua sektor, terutama dunia pendidikan. Meski demikian, pembelajaran harus tetap terlaksana di masa pandemi ini. Terhitung sejak 16 Maret 2020, pemerintah menerapkan pembelajaran jarak jauh guna mengurangi penyebaran virus tersebut sebagai usaha agar proses belajar mengajar tetap berjalan dengan kondusif di masa pandemi ini. Pembelajaran yang terlaksana hingga saat ini dikenal dengan pembelajaran daring (dalam jaringan) atau online.

Beruntungnya kita saat ini berada di era dimana teknologi berkembang pesat dan tentunya memiliki pengaruh besar terhadap pendidikan, sehingga sangat membantu dalam pembelajaran baik secara luring maupun daring. ${ }^{1}$ Sejalan dengan hal tersebut, pelaksanaan pembelajaran jarak jauh mendorong guru untuk memanfaatkan berbagai platform, media sosial atau aplikasi sebagai media pembelajaran dan komunikasi dengan peserta didik. Terdapat dua macam pembelajaran daring, yakni secara sinkron maupun asinkron. Pembelajaran sinkron adalah sistem pembelajaran yang membutuhkan jaringan internet guna adanya komunikasi dalam satu waktu tanpa jeda antara peserta didik dan pengajar. ${ }^{2}$ Pembelajaran ini sangat dibutuhkan agar terjadi interaksi atau umpan balik secara langsung. Pembelajaran sinkron dapat dilakukan melalui pertemuan tatap muka yaitu fitur video conference melalui berbagai platform dan aplikasi: Google Meet, Microsoft Teams, Zoom, dll. Sedangkan pembelajaran asinkron merupakan sistem pembelajaran dalam waktu yang berbeda, dengan kata lain peserta didik dan pendidik mengakses materi secara tidak langsung, pembelajaran ini biasanya digunakan untuk penugasan. Beberapa platform atau aplikasi yang dapat digunakan pada pembelajaran asinkron adalah Google Classroom, Microsoft Office 365, Microsoft Teams, Schoology dan lainnya. ${ }^{3}$ Sebagai media pembelajaran, platform tersebut memang penting untuk dikuasai oleh guru agar dapat menyajikan bahan ajar yang variatif dan berbagai model latihan kepada peserta didik.

Ditengah pandemi seperti sekarang ini, peran e-learning dapat dinilai sangat cocok digunakan oleh peserta didik dalam pembelajaran, serta pengajaran oleh guru dalam menggunakan fasilitas system electronic learning yang telah disediakan. Aplikasi e-learning saat ini banyak dikenal oleh

${ }^{1}$ Siti Nurul Fitriani, Syarifah Syarifah, dan Ali Susanto, "Pembelajaran Bahasa Arab Interaktif Melalui Media E-Learning Madrasah di MTsN 1 Kota Malang,” Tarbiyatuna: Jurnal Pendidikan Ilmiah 5, no. 2 (2020): 159-82.

2 Andi Sulistio, "Peningkatan Prestasi Belajar Bahasa Inggris Melalui Pembelajaran Jarak Jauh (PJJ) dalam Penerapan Pembelajaran Sinkron dan Asinkron Melalui Google Classroom, Google Meet Dan Aplikasi ELearning," SECONDARY: Jurnal Inovasi Pendidikan Menengah 1, no. 2 (2021): 63-69.

3 Shofaul Hikmah, "Pemanfaatan e-learning Madrasah dalam Pelaksanaan Pembelajaran Jarak Jauh Masa Pandemi di MIN 1 Rembang," Edutrained J. Pendidik. dan Pelatih 4, no. 2 (2020): 73-85. 
pendidik sebagai salah satu resolusi dalam mengatasi masalah pendidikan maupun pelatihan. ${ }^{4}$ Memanfaatkan e-learning sebagai media pembelajaran daring atau online, dapat mempermudah peserta didik dalam proses pembelajaran serta sebagai pelengkap maupun suplemen peserta didik agar mampu meningkatkan pemahaman mereka mengenai mata pelajaran khususnya bahasa arab. Dalam sebuah penelitian yang berjudul "Pemanfaatan E-learning pada Pembelajaran Jarak Jauh di Masa Pandemi Covid-19" yang ditulis oleh Pipit Putri Hariani dan kawan-kawan mengemukakan bahwa keberhasilan pembelajaran online perlu adanya beberapa pihak yang harus terlibat karena pembelajaran online tidak berbeda jauh dengan pembelajaran umum. Secara psikologis peserta didik juga membutuhkan perhatian dari guru, orang tua, serta lingkungan yang mendukung. Sehingga, orang tua harus memberikan waktu lebih kepada anaknya. ${ }^{5}$ Serta motivasi juga perlu diberikan oleh guru kepada peserta didik melalui komunikasi dalam pembelajaran.

Dalam pembelajaran terutama dalam bidang bahasa, sistem sinkron maupun asinkron sangat penting untuk dilakukan keduanya, agar tujuan pembelajaran tercapai dengan maksimal. E-learning madrasah merupakan sebuah inovasi dari Kementrian Agama sebagai media pembelajaran di masa pandemi guna memfasilitasi guru dan peserta didik khususnya madrasah yang berada di bawah naungan Kemenag. E-learning memfasilitasi guru dan peserta didik untuk melakukan pembelajaran dan pengajaran secara sinkron dan asinkron melalui berbagai fitur didalamnya. Seperti yang telah disebutkan oleh Siti Nurul Fitriani, dkk dalam penelitiannya, fitur e-learning madrasah mencakup Video Conference, Teaching Materials, Learning Plans, Class Attendance, Class Timeline, Minimum Completeness Criteria, Associated Student Data, Teacher's Journal, Computer Based Test (CBT), Student Activity Monitoring, Final Semester Assessment, Knowledge Assessment (KI3), Skill Assessment (KI4), dan juga Report Card Recapitulation, yang tentunya dapat dimanfaatkan untuk pembelajaran bahasa arab. Maka dari itu, penelitian ini menelusuri rumusan masalah berikut:

1. Bagaimana efektivitas e-learning madrasah sebagai media pembelajaran bahasa Arab di MTsN 2 kota Surabaya di era pandemi?

2. Bagaimana fitur aplikasi e-learning madrasah untuk mengembangkan kemampuan bahasa Arab di MTsN 2 kota Surabaya di era pandemi?

3. Bagaimana model soal yang diberikan guru melalui fitur pada e-learning madrasah sebagai media pembelajaran Bahasa Arab di MTsN 2 Kota Surabaya di Era Pandemi?

4. Apa saja kendala yang dihadapi oleh guru dalam menerapkan e-learning madrasah sebagai media pembelajaran Bahasa Arab di MTsN 2 Kota Surabaya di Era Pandemi?

\footnotetext{
4 Fitriani, Syarifah, dan Susanto, "Pembelajaran Bahasa Arab Interaktif Melalui Media E-Learning Madrasah di MTsN 1 Kota Malang," 160.

5 Pipit Putri Hariani dan Sri Ngayomi Yudha Wastuti, "Pemanfaatan e-learning pada pembelajaran jarak jauh di masa pandemi covid-19," Biblio Couns: Jurnal Kajian Konseling dan Pendidikan 3, no. 2 (2020): 41-49.
} 


\section{B. Kajian Teori}

\section{E-learning Madrasah sebagai Media Pembelajaran}

Media pembelajaran merupakan perangkat, serta metode yang digunakan sebagai alat komunikasi maupun interaksi antara pendidik dan peserta didik agar pembelajaran menjadi lebih efektif ketika proses pembelajaran dan pengajaran berlangsung di sekolah. 6 Terkait dengan media pembelajaran, Siti Nurul Fitriani dkk mengemukakan pengertian e-learning dibagi menjadi 2 bagian, yang pertama "E" merupakan singkatan dari electronic serta "learning" maksudnya yakni pendidikan. Jadi E-learning merupakan teknologi informasi sebagai fasilitas peserta didik untuk belajar kapanpun dan dimanapun. ${ }^{7}$ Ahmad Fadilah Khomsah ${ }^{8}$ dalam sebuah penelitiannya mengemukakan tujuan dari e-learning yakni untuk mentransfer ilmu pengetahuan maupun informasi yang digunakan untuk meningkatkan keterampilan peserta didik dengan memanfaatkan jaringan internet.

Adapun tujuan dari e-learning yakni dijadikan sebagai media untuk meningkatkan kualitas pelaksanaan proses pembelajaran peserta didik, mengubah pembelajaran peserta didik yang sebelumnya pasif menjadi aktif, mengubah cara yang dilakukan pendidik dalam proses pengajaran, memberikan peluang belajar kepada masyarakat lebih luas, serta dapat mengembangkan serta memperluas produk dan layanan baru. Sedangkan manfaat penggunaan dari e-learning yakni terdapat peningkatan mutu pembelajaran oleh peserta didik serta pendidik, tidak ada batasan pembelajaran oleh ruang dan waktu yang mana proses pembelajaran tersebut tidak dilakukan tatap muka, materi mudah diakses karena disampaikan melalui e-learning, dan meningkatkan kualitas dari pembelajaran, pelayanan, serta kepuasan yang dirasakan oleh pendidik. ${ }^{9}$

Kelebihan yang dimiliki aplikasi e-learning yakni dapat diakses kapanpun, bahan-bahan pembelajaran mudah diakses serta mampu mewujudkan persepsi pembelajaran yang praktis dan efektif. Sedangkan kelemahan yang dimiliki fitur e-learning yaitu biaya yang dikeluarkan menjadi lebih banyak untuk kebutuhan kuota internet, ${ }^{10}$ terkadang masalah jaringan karena tempat tinggal peserta didik yang berada di pedalaman desa, serta kurang adanya interaksi sosial sesama murid

6 Joko Kuswanto dan Ferri Radiansah, "Media Pembelajaran Berbasis Android Pada Mata Pelajaran Sistem Operasi Jaringan Kelas XI," Jurnal Media Infotama 14, no. 1 (2018): 16.

7 Fitriani, Syarifah, dan Susanto, "Pembelajaran Bahasa Arab Interaktif Melalui Media E-Learning Madrasah di MTsN 1 Kota Malang,” 161.

8 Ahmad Fadilah Khomsah dan Muassomah Muassomah, "Penerapan E-learning dalam Pembelajaran Bahasa Arab di Masa Pandemi," Tarbiyatuna: Jurnal Pendidikan Ilmiah 6, no. 1 (2021): 1-14.

9 Fitriani, Syarifah, dan Susanto, "Pembelajaran Bahasa Arab Interaktif Melalui Media E-Learning Madrasah di MTsN 1 Kota Malang," 166. 19."

${ }^{10}$ Hariani dan Wastuti, "Pemanfaatan e-learning pada pembelajaran jarak jauh di masa pandemi covid- 
secara langsung yang mana biasanya dapat dilakukan ketika pembelajaran offline oleh peserta didik.

Dari beberapa pendapat diatas, peneliti menyimpulkan bahwa e-learning ialah media pembelajaran yang berbasis teknologi yang dapat diakses melalui berbagai perangkat (komputer, laptop, maupun smartphone) untuk memfasilitasi proses pembelajaran daring di era pandemi yang dapat diakses oleh peserta didik tanpa terikat waktu dan tempat. E-learning madrasah adalah aplikasi gratis yang dirancang oleh Kementrian Agama yang digunakan sebagai media pembelajaran agar memudahkan proses pengajaran serta pembelajaran lebih terstruktur dan interaktif. Ada enam hak akses yang ada pada e-learning madrasah, diantaranya yakni: Siswa, Guru Mapel (mata pelajaran), Wali Kelas, Administrasi, Guru BK, dan Supervisor yang terdiri atas kepala madrasah serta jajarannya. ${ }^{11}$

\section{Peran Bahasa Arab dalam Dunia Pendidikan}

PBB (perserikatan bangsa-bangsa) menggunakan Bahasa Arab sebagai bahasa Internasional dan juga bahasa resmi, bahasa Arab juga bahasa umat islam serta bahasa kitab suci Al-Qur'an dan Hadits (Anshori). Di negara kita bahasa Arab juga digunakan sebagai bahasa kedua, masyarakat Indonesia tidak memakai Bahasa Arab sebagai bahasa yaumiya, sehingga dianggap sebagai bahasa asing. Pernyataan tersebut menggambarkan bahwa bahasa Arab memiliki peran penting sehingga perlu dipelajari dan dipraktekkan dalam dunia pendidikan. Di dunia pendidikan, bahasa Arab tidak digunakan sebagai bahasa pengantar, namun diajarkan dengan mata pelajaran tertentu dengan menggunakan modul. Bahasa asing merupakan sistem pembelajaran yang digunakan, mulai dari tujuan pembelajaran, materi, serta metode yang digunakan. ${ }^{12}$

Bangsa Indonesia khususnya pelajar, memandang bahasa Arab secara linguistik sebagai bahasa asing, bukan sebagai bahasa ibu. Setiap orang mempunyai pandangan yang berbeda dalam menilai belajar bahasa Arab. Ada yang memandang sebagai religious language, karena bahasa Arab dilihat sebagai perantara untuk memahami serta memperdalam bacaan kitab suci Islam. Pendapat lain memandang belajar bahasa Arab merupakan Islamic science, karena mayoritas ilmu-ilmu yang terkandung dalam ilmu pengetahuan Islam berbahasa Arab. Serta ada yang memandang belajar bahasa Arab merupakan learn a language, karena mereka menganggap sebagai bahasa komunikasi. Perbedaan perspektif yang berbeda tentunya mempunyai perbedaan tata cara, media

${ }^{11}$ Kemenag, "E-Learning Madrasah Official," https://elearning.kemenag.go.id/, diakses 28 Desember 2021, https://elearning.kemenag.go.id/.

12 Meidiana Sahara Riqza dan M. Muassomah, "Media Sosial untuk Pembelajaran Bahasa Arab pada Masa Pandemi: Kajian Kualitatif Penggunaan WhatsApp pada Sekolah Dasar di Indonesia," Alsina: Journal of Arabic Studies 2, no. 1 (2020): 71-94. 
pembelajaran, metode, strategi, bahan ajar dan penilaian dalam proses pembelajaran. Sedangkan jika peserta didik mempunyai tujuan agar peserta didik dapat melatih maharah kalam maka lebih memperbanyak hafalan mufrodat sebagai bahan praktik dialog berbahasa Arab. ${ }^{13}$

Setiap materi yang terdapat pada pembelajaran bahasa arab mencakup empat maharah (keterampilan), yaitu istima' wa kalam (mendengar dan berbicara), Qira'ah wal kitabah (membaca dan menulis). Maharah Istima' merupakan maharah awal yang harus diperhatikan dalam belajar bahasa asing. Siapapun yang mempelajari bahasa asli maupun asing mereka harus menguasai maharah istima' atau keterampilan menyimak. Sedangkan maharah kalam (berbicara) berhubungan dengan bahasa lisan. Maharah kalam merupakan keterampilan yang harus dikuasai oleh seseorang dalam belajar bahasa asing setelah maharah istima', karena sulit untuk seseorang yang memiliki pendengaran buruk untuk berbicara dengan menggunakan bahasa yang tidak dipahami orang lain. Mahara qira'ah (keterampilan membaca) merupakan keterampilan yang dimiliki seseorang tentang menafsirkan bentuk-bentuk bahasa tertulis baik berupa kata, kalimat, maupun paragraf yang dibacanya. Kemudian keterampilan yang harus dimiliki seseorang yakni Maharah kitabah (keterampilan menulis), kitabah merupakan aktivitas yang dilakukan setiap orang untuk menghasilkan sebuah catatan atau informasi yang dapat dipahami oleh pembaca. Dalam maharah kitabah pada pembelajaran bahasa Arab ada beberapa aspek yang perlu diperhatikan, yaitu kosa kata, qawaid (tata bahasa), balaghah (sastra), dan memilih sebuah kamus yang sesuai. ${ }^{14}$ Jadi, kegiatan menulis harus memperhatikan beberapa aspek tersebut, agar tulisan yang ditulis secara tidak langsung dapat memudahkan pembaca.

Sebagai sumber utama belajar bahasa Arab di era industri 4.0 kita dapat memanfaatkan information and communication technology, salah satunya dengan menggunakan internet. Belajar bahasa Arab di era milenial dapat belajar dengan sistem satu hari satu kalimat, dan satu hari satu cerita. Kita juga dapat belajar melalui berita-berita melalui surat kabar elektronik maupun digital yang berhubungan dengan bahasa arab seperti al-Ahrom, al-Jazeera, dan lain-lain. Dengan begitu kita dapat mengetahui istilah-istilah baru sesuai dengan perkembangan zaman sekarang. Tidak hanya melalui surat kabar elektronik maupun digital saja, tetapi kita juga dapat memanfaatkan youtube dengan mencari lagu-lagu arab dan bernyanyi. Secara tidak langsung kita belajar pengucapan dan mufrodat (kosa kata) baru. ${ }^{15}$

\footnotetext{
13 Nanang Kosim dkk., "Pembelajaran bahasa Arab melalui daring: Problematika, solusi dan harapan," Work From Home, 2020.

14 Khomsah dan Muassomah, "Penerapan E-learning dalam Pembelajaran Bahasa Arab di Masa Pandemi," 4.

15 Cahya Edi Setyawan dan Khairul Anwar, "Peran Bahasa Arab Dalam Pendidikan Islam Sebagai Urgensitas Menghadapi Revolusi Industri 4.0," Lahjah Arabiyah: Jurnal Bahasa Arab Dan Pendidikan Bahasa Arab 1, no. 1 (2020): 11-19.
} 


\section{Pembelajaran di Era Pandemi}

Pada awal tahun 2020 beberapa sektor di Indonesia mengalami dampak dari adanya pandemi covid-19 (Coronavirus Disease of 2019), salah satunya yakni pada sektor pendidikan. Pandemi ialah banyaknya wabah yang menyerang banyak orang serta menyebar di berbagai negara serta benua. Sedangkan yang dimaksud wabah yakni sebutan yang digunakan untuk mengenali kenaikan jumlah permasalahan penyakit secara tiba-tiba pada populasi zona tertentu.

Penggabungan kata "dalam jaringan" atau yang dikenal dengan daring memiliki arti sebuah aktivitas yang dilakukan secara online dengan memanfaatkan internet. Yang dimaksud dengan pembelajaran daring yakni kegiatan pembelajaran yang memiliki target luas dan kuat dengan memanfaatkan beberapa teknologi multimedia seperti streaming video melalui google meet atau zoom, voice note, email dan lain sebagainya. ${ }^{16}$ Sebelum adanya pandemi pembelajaran dilaksanakan secara offline kini beralih menjadi online. Pembelajaran tersebut memanfaat perkembangan teknologi yang mana saat ini kita berada di era industri pendidikan 4.0. Dari banyaknya berbagai media pembelajaran yang digunakan salah satunya yakni e-learning madrasah sebagai media pembelajaran jarak jauh, yang mana memiliki beberapa kelebihan dan kelemahan di dalam situs aplikasi e-learning tersebut.

Di masa pandemi sekarang ini, Teddy Meilwansyah ${ }^{17}$ selaku kepala dinas Kab. Oku mengemukakan bahwasannya ada tujuh macam cara yang dapat digunakan pada pembelajaran jarak jauh atau online, diantaranya yakni: Pertama, Pembelajaran Berbasis Proyek, pembelajaran ini bertujuan memberikan pelatihan peserta didik agar dapat mutual cooperation serta empathy dengan sesama. Metode ini sangat cocok diterapkan pada wilayah aman dari virus covid-19 dengan anjuran menerapkan protokol kesehatan. Cara ini sangat efektif untuk diterapkan karena peserta didik dapat membentuk small study group ketika membuat projek, inovasi maupun eksperimen. Kedua, Pembelajaran Online (Daring Method) merupakan pembelajaran yang memanfaatkan jaringan online yang mana peserta didik dapat lebih kreatif menggunakan barang-barang yang ada atau fasilitas yang terdapat di sekitarnya, untuk dijadikan sebuah konten kegiatan belajar dengan bentuk online. Metode ini cocok digunakan pada zona merah, karena pembelajarannya yang bersifat full daring. Jadi peserta didik siswi tetap dalam keadaan aman di rumah masing-masing.

Ketiga, Pembelajaran Luar jaringan (Luring Method) merupakan Sistem pembelajaran metode ini yakni shift model (secara bergiliran) agar tidak terjadi kerumunan. Metode ini cocok digunakan pada zona aman dari virus covid-19 dengan anjuran menerapkan protokol kesehatan. Sedangkan

16 Khomsah dan Muassomah, "Penerapan E-learning dalam Pembelajaran Bahasa Arab di Masa Pandemi," 5.

17 Teddy Meilwansyah, "Pembelajaran di Masa Pandemi Covid-19," diakses 28 Desember 2021, https://diknas.okukab.go.id/berita/detail/pembelajaran-di-masa-pandemi-covid19. 
pembelajaran ini dinilai cukup baik untuk dilaksanakan bagi madrasah yang kekurangan fasilitas sekolah. Keempat, Home Visit Method merupakan metode yang mirip seperti kegiatan pembelajaran yang dilakukan ketika homeschooling. Guru berkunjung ke rumah peserta didik dengan jadwal yang ditentukan untuk memberikan materi kepada peserta didik agar tersampaikan dengan baik di bawah bimbingan guru.

Kelima, Kurikulum Terintegrasi (Integrated Curriculum) merupakan metode yang tidak hanya melibatkan materi pembelajaran dari mata pembelajaran lainnya dengan merujuk pada basis proyek. Metode ini diterapkan dengan sistem daring dan cocok digunakan seluruh pelajar di semua wilayah. Jadi, pembelajaran dengan metode Integrated Curriculum sangat aman bagi peserta didik. Keenam, Pembelajaran Campuran (Blended Learning) merupakan pembelajaran yang menggunakan dua metode pendekatan sekaligus, yakni dengan sistem online dan tatap muka melalui video conference. Meskipun pembelajaran dilakukan jarak jauh pengajar dan peserta didik dapat berinteraksi satu sama lain melalui video conference tersebut. Metode ini cocok digunakan untuk meningkatkan kemampuan kognitif peserta didik. Ketujuh, Pembelajaran melalui radio merupakan salah satu metode untuk mengatasi kesulitan peserta didik dalam mengakses internet serta solusi bagi orang tua yang tidak memiliki smartphone. Pembelajaran melalui radio dilakukan oleh guru yang kompeten serta peserta didik sebagai pendengar .

\section{Metode Penelitian}

\section{Pendekatan dan Desain Penelitian}

Penelitian kualitatif merupakan penelitian yang sangat cocok untuk menginvestigasi rumusan masalah yang variabelnya belum diketahui dan perlu untuk dieksplor. ${ }^{18}$ Hal tersebut sejalan dengan tujuan penelitian ini yaitu mengeksplor bagaimana model soal yang diberikan guru melalui fitur pada e-learning serta kendala yang dihadapi oleh guru dalam menerapkan e-learning sebagai media pembelajaran Bahasa Arab di MTsN 2 Kota Surabaya di Era Pandemi. Guna menyajikan data, peneliti memilih untuk menggunakan metode deskriptif kualitatif sehingga data dapat tereksplor secara detail.

\section{Data dan Sumber Data}

Data penelitian ini adalah penjelasan mengenai model soal yang diberikan guru melalui fitur pada e-learning serta informasi terkait kendala yang dihadapi oleh guru dalam menerapkan elearning sebagai media pembelajaran Bahasa Arab di MTsN 2 Kota Surabaya di Era Pandemi ini. Untuk mendapatkan data tersebut, peneliti membutuhkan informasi dari guru Bahasa Arab MTsN 2

${ }^{18}$ John W. Creswell, Educational research: Planning, conducting, and evaluating quantitative, 4 ed. (Baston, MA: Pearson, 2012), 16. 
Kota Surabaya yang merupakan salah satu madrasah yang menerapkan e-learning madrasah dengan maksimal. Maka dari itu, peneliti perlu melakukan interview dan analisis aplikasi e-learning guna mengumpulkan data. Beberapa sumber lainnya juga diperlukan untuk membangun pemahaman peneliti mengenai aplikasi e-learning madrasah.

\section{Proses Pengumpulan Data}

Pada penelitian ini ada beberapa tahap proses pengumpulan data yaitu: Pertama, peneliti menetapkan judul dan membuat rumusan masalah dari topik yang ingin diinvestigasi, yaitu berfokus pada pembelajaran bahasa Arab dengan media pembelajaran yang digunakan, yang mana terjadi di era pandemi ini. Sehingga menetapkan MTsN 2 Kota Surabaya sebagai target untuk penelitian ini. Kedua, peneliti memilih desain penelitian yang sesuai dengan kebutuhan peneliti dalam menjawab rumusan masalah. Ketiga, peneliti menyusun instrumen penelitian berupa interview guideline yang dibutuhkan untuk mengumpulkan data. Keempat, peneliti mulai mengumpulkan data melalui interview dan analisis e-learning madrasah yang digunakan oleh guru bahasa Arab terkait dalam mengajar.

Proses wawancara dilakukan secara langsung oleh peneliti, kemudian direkam dan dicatat. Rekaman tersebut dibutuhkan agar peneliti dapat mentranskrip hasil interview dengan seksama. Untuk itu, peneliti menggunakan beberapa alat bantu antara lain:

a. Interview Guideline, Guna mengumpulkan informasi terkait fitur dan kendala e-learning madrasah sebagai pembelajaran bahasa Arab di era pandemi ini, peneliti menggunakan model interview semi-terstruktur. Terdapat 15 pertanyaan yang terkait dengan 2 rumusan masalah yang telah ditetapkan.

b. Field Note. Dalam menganalisis aplikasi e-learning madrasah, peneliti belum memiliki pandangan tentang apa yang ada di dalamnya, maka dari itu peneliti menggunakan field note untuk mencatat informasi terkait fitur yang ada didalamnya serta hal lain yang berhubungan dengan pembelajaran bahasa Arab melalui e-learning madrasah selama era pandemi ini. Peneliti berharap dengan menggunakan field note, data dapat dieksplorasi lebih detail.

c. Rekaman. Jenis rekaman yang digunakan sebagai instrumen pada penelitian ini adalah rekaman audio yang didapatkan oleh peneliti saat melakukan wawancara kepada guru MTsN 2 Kota Surabaya sebagai narasumber secara langsung. Peneliti merekam hasil wawancara tersebut agar data tetap tersimpan dan peneliti tidak perlu khawatir akan tertinggal dalam mencatat informasi yang didapat dari partisipan selama interview. 


\section{Teknik Analisis Data}

Setelah mengumpulkan data melalui interview dan analisis terkait dengan fitur yang sering digunakan serta kendala yang dialami guru bahasa Arab pada e-learning madrasah di era pandemi ini, peneliti mentranskrip rekaman suara hasil interview yang diperlukan untuk analisis data. Lalu, peneliti membaca transkrip interview dan field note hasil analisis pada aplikasi e-learning madrasah dengan seksama. Setelah dibaca, data dirangkum dan di kode agar data semakin jelas.

Setelah itu, data diinterpretasikan agar pembaca dapat membaca penemuan atau hasil penelitian dengan mudah. Setelah hasil penelitian serta pembahasan tersusun, peneliti melakukan validasi data dengan mengecek aplikasi e-learning madrasah yang digunakan oleh Guru terkait. Tidak hanya itu, kesimpulan dan saran kepada guru terkait kendala penggunaan e-learning madrasah khususnya dalam pembelajaran bahasa Arab di era pandemi ini juga dituliskan oleh peneliti di akhir penelitian.

\section{Hasil dan Pembahasan}

\section{Efektivitas E-Learning Madrasah sebagai Media Pembelajaran Bahasa Arab}

Berdasarkan hasil wawancara Guru MTsN 2 Kota Surabaya, dalam pembelajaran bahasa Arab e-learning madrasah dirasa cukup efektif dalam pemberian latihan, bahan ajar, maupun tes terkait pengetahuan dan keterampilan. Guru 1 mengemukakan bahwa e-learning cukup memenuhi kebutuhan dalam pembelajaran bahasa Arab. Namun Guru 2 menambahkan bahwa seharusnya beberapa hal dalam e-learning yang menjadi kendala terutama dalam pengajaran bahasa Arab perlu untuk diperbaiki.

Pernyataan peneliti di atas diperkuat dengan penelitian yang dilakukan oleh Shofaul Hikmah $^{19}$ yang menyatakan bahwa e-learning Madrasah telah dibuktikan bermanfaat dalam pembelajaran di masa pandemi Covid-19 sehingga menjadi pilihan utama serta sarana yang memfasilitasi kegiatan pengajaran dan pembelajaran daring di MIN 1 Rembang pada masa pandemi ini.

\section{Fitur Aplikasi E-Learning Madrasah untuk Mengembangkan Kemampuan Bahasa Arab}

Peran akses pada aplikasi e-learning sebagai guru memiliki beberapa fitur diantaranya yakni: (1) fitur forum berfungsi untuk diskusi online atau menyampaikan informasi tertulis kepada warga madrasah yang dapat dilihat oleh guru maupun peserta didik. (2) Fitur kelas online digunakan oleh guru untuk membuat beberapa kelas online sesuai dengan kelas yang diajarnya. (3) fitur kalender

19 Hikmah, "Pemanfaatan e-learning Madrasah dalam Pelaksanaan Pembelajaran Jarak Jauh Masa Pandemi di MIN 1 Rembang," 73. 
digunakan untuk melihat kalender akademik yang dibuat oleh administrator. (4) fitur komunikasi digunakan oleh guru untuk mengirimkan pesan pribadi kepada guru yang dipilihnya. (5) fitur notifikasi, berfungsi untuk menampilkan informasi yang berkaitan dengan guru. Seperti ketika peserta didik sedang mengerjakan atau mengumpulkan tugas serta pemberitahuan ketika peserta didik atau guru mengomentari mengenai informasi yang telah disampaikannya. (6) fitur absensi, berfungsi untuk mengetahui kehadiran guru yang dipantau secara langsung oleh kepala madrasah. (7) Fitur Guru online, berfungsi untuk menampilkan guru yang online secara real-time. (8) Fitur Siswa online, memiliki fungsi yang sama yaitu menampilkan peserta didik yang sedang online secara real-time. (9) profil anda, berisi tentang profil guru yang mengajar di madrasah tersebut. (10) fitur wali kelas, khusus digunakan guru yang terpilih menjadi wali kelas saja.

Untuk guru yang ingin memulai pembelajaran kelas online bisa mengklik fitur kelas online yang telah dibuatnya. Di dalam kelas online juga terdapat beberapa fitur yang dapat meningkatkan kemampuan bahasa arab. Diantaranya menu utama yakni (1) fitur forum, digunakan untuk diskusi materi yang belum dipahami oleh peserta didik. (2) fitur timeline, digunakan untuk berkomunikasi secara tertulis antara guru dan peserta didik dalam satu kelas saja. (3) fitur video conference, berfungsi untuk guru yang menginginkan pembelajaran secara virtual dengan peserta didik. (4) fitur kompetensi, digunakan untuk mengupload kompetensi inti (KI), kompetensi dasar (KD) pengetahuan dan keterampilan yang sesuai dengan mata pelajaran kelasnya. (5) fitur KKM, berfungsi untuk mengupload KKM mata pelajaran yang sesuai dengan kelas dan semester. (6) fitur RPP, digunakan oleh guru untuk membuat rencana pembelajaran. (7) fitur bahan ajar, digunakan untuk membagikan materi yang telah disiapkan oleh guru kepada peserta didik. Formatnya dapat berbentuk word, PDF, PPT, excel, video pembelajaran maupun link artikel. (8) fitur data siswa tergabung, memiliki fungsi guna untuk memasukkan peserta didik pada setiap kelas mata pelajaran. (9) fitur absensi, berfungsi untuk menampilkan kehadiran peserta didik. dapat dilihat setiap kelas, setiap pertemuan, maupun setiap bulan. (10) fitur jurnal, berfungsi sebagai catatan setiap peristiwa yang terjadi pada peserta didik ketika dalam proses pembelajaran, sehingga wali kelas dan Guru BK dapat melihat secara langsung. (11) ujian CBT, dimanfaatkan oleh guru untuk membuat soal latihan atau ujian. (12) Penilaian KI 3 (pengetahuan), digunakan untuk membuat soal maupun tugas sebagai bentuk nilai harian. (13) penilaian KI 4 (keterampilan), digunakan untuk mengukur keterampilan peserta didik, bisa berbentuk portofolio atau produk. (14) fitur PAS, pada fitur ini peserta didik dapat melihat nilai PAS dan nilai akhir. Yang mana nilai tersebut dapat input secara manual atau secara otomatis dari nilai hasil ujian melalui CBT. (15) fitur rapor, digunakan untuk merekap nilai akhir peserta didik, baik nilai pengetahuan maupun keterampilan. (16) fitur monitoring, berfungsi untuk menampilkan aktivitas peserta didik dalam setiap kelas. (17) fitur 
kalender, peserta didik dapat melihat jadwal ulangan harian, ujian maupun tugas yang diberikan oleh setiap guru mapel. (18) fitur pengaturan, melalui fitur ini guru dapat mengubah data kelas online apabila di awal terdapat kesalahan ketika menginput data. (19) fitur notifikasi, berfungsi sebagai tempat informasi pengumuman yang telah disampaikan oleh guru baik mengenai tugas maupun yang lain dalam 1 kelas.

Untuk meningkatkan maharah istima' wa kalam (keterampilan menyimak dan berbicara) guru menggunakan fitur bahan ajar dengan membagikan sebuah video atau audio untuk disimak kemudian peserta didik mempraktekkan apa yang telah dilihat dalam bentuk video. Kemudian peserta didik mengumpulkan hasil tugasnya melalui fitur pengumpulan tugas untuk dinilai oleh guru. Pembelajaran yang dilakukan oleh Guru 1 juga melakukan pembelajaran melalui video conference yang mana peserta didik dapat praktek dialog dengan temannya secara langsung dihadapan guru. Sedangkan guru 2 hanya sesekali saja menggunakan video conference dengan sapaan-sapaan dalam bahasa Arab, karena tidak memungkinkan praktek dialog dengan temannya. Namun guru 2 juga tetap menyampaikan materi tentang bagaimana dialog yang baik, melafalkan bacaan Arab serta lahjah arabiyah yang tepat melalui bahan ajar.

Untuk meningkatkan maharah qira'ah (keterampilan membaca) guru menggunakan fitur bahan ajar berbentuk PDF/PPT yang isinya teks bacaan sederhana sesuai KD untuk dibaca dan dipahami oleh peserta didik. Kemudian guru memberikan latihan melalui fitur CBT untuk melihat sejauh mana kemampuan peserta didik mengenai maharah qira'ah. Secara garis besar, keterampilan membaca ada 2 jenis, yaitu: al-qira'ah al-jahriyah (membaca nyaring) dan al-qira'ah al-shamitah (membaca dalam hati). Untuk al-qira'ah al-jahriyah guru memberi tugas kepada peserta didik membuat video membaca teks arab kemudian disetorkan di e-learning untuk dinilai oleh guru agar mengetahui sejauh mana peserta didik menguasai keterampilan membaca. Sedangkan untuk meningkatkan maharah kitabah (keterampilan menulis) guru memberikan latihan tes melalui fitur CBT, menyalin teks dari media tertentu ke dalam buku kemudian disetorkan kepada guru melalui fitur pengumpulan tugas, terkadang guru juga memberikan tugas membuat tulisan sederhana sesuai KD yang diajarkan.

\section{Model Soal dalam Penilaian Yang Diberikan Guru Melalui Fitur pada E-Learning Madrasah sebagai Media Pembelajaran Bahasa Arab di MTsN 2 Kota Surabaya}

Pada dasarnya penilaian pembelajaran bahasa Arab juga sama halnya dengan penilaian mata pelajaran lainnya, yakni diambil dari KI 3 dan KI 4 yang meliputi aspek pengetahuan dan keterampilan. Meskipun di masa pandemi ini pembelajaran kurang terlaksana dengan maksimal sebagaimana dalam pembelajaran tatap muka, namun guru juga tetap berusaha untuk menekankan 
keterampilan produktif juga pada peserta didik. Penilaian KI 3 dan penilaian KI 4 tersebut dituangkan ke dalam fitur terpisah sehingga jelas untuk guru dalam memberi tugas, menilai, mengakumulasi.

Penilaian pengetahuan dan keterampilan peserta didik dilakukan dalam bentuk written test, oral test, or assignment. Written Test yang diberikan dapat berupa pilihan ganda, essay, menjodohkan, dll. Untuk oral test berupa quiz dan question and answer melalui kelas. Untuk penugasan guru memberi tugas sesuai materi yang disampaikan kepada peserta didik baik individu maupun kelompok. Selain itu peserta didik dituntut untuk kreatif dengan pemberian tugas berupa praktik, produk/portofolio.

I Wayan Redhana ${ }^{20}$ berpendapat bahwa bekerja kreatif dengan teman ataupun orang lain dapat: (1) mengkomunikasikan, mengembangkan, serta menerapkan berbagai ide, saran serta feedback baru secara efektif, (2) open-minded terhadap perspektif yang unik dan baru (3) menghasilkan keaslian dan kebaruan karya/tugas dan memahami bagaimana batasan dalam mengadopsi ataupun mengadaptasi ide baru, dan juga (4) menganggap kegagalan sebagai kesempatan untuk belajar.

Guru 1 dan guru 2 melakukan penilaian terkait keterampilan membaca dengan cara memberikan bacaan dan beberapa model soal, antara lain: pilihan ganda, isian, dan essay yang disediakan oleh e-learning madrasah. Tidak hanya itu, dalam keterampilan berbicara murid diminta untuk membuat video dan juga dinilai dari kemampuan mereka saat berbicara ketika melakukan video conference atau pertemuan secara daring. Dalam keterampilan menyimak, peserta didik diberikan video atau audio yang diberikan dalam bentuk link. Setelah mengakses video/audio tersebut, peserta didik akan diberikan beberapa soal untuk mengukur sejauh mana pemahaman peserta didik mengenai materi yang telah disampaikan oleh guru.

Namun Guru 1 dan Guru 2 berbeda dalam memberikan latihan soal dan penilaian terkait kemampuan menulis. Guru 1 hanya memberikan model soal fill in the blank, short answer, essay melalui fitur Penilaian Pengetahuan dan juga Penilaian Keterampilan. Sedangkan Guru 2 selaku guru yang mengajar kelas menengah memberikan soal fill in the blank, short answer, serta essay dan juga meminta peserta didik untuk create atau membuat karangan tulisan sederhana seperti perkenalan dan lainnya sesuai dengan KD tertentu. Sehingga peserta didik terdorong untuk berpikir kritis, tidak hanya menyelesaikan soal yang ada tetapi juga menyusun dan mengarang apa saja yang ingin mereka eksplor. Kemudian peserta didik dapat mengumpulkan berupa jawaban

20 I. Wayan Redhana, "Mengembangkan keterampilan abad ke-21 dalam pembelajaran kimia," Jurnal Inovasi Pendidikan Kimia 13, no. 1 (2019). 
yang di foto kemudian di upload ke dalam fitur e-learning madrasah yang telah disiapkan oleh guru masing-masing.

Ade Cahyana ${ }^{21}$ dalam makalah singkatnya mengemukakan bahwa creating merupakan sebuah kemampuan kognitif guna menyusun informasi yang telah didapat dengan ide baru yang menggabungkan unsur-unsur terkait objek konsep baru yang terdiri dari problem solving, planning serta menghasilkan sebuah produk. Creating merupakan salah satu langkah atau langkah terakhir dalam Higher Order Thinking. Sebuah penelitian yang dilakukan oleh Yuli Wahyuningsih, dkk mengutip teori dari Saputra mengenai tujuan HOTS yaitu untuk mengasah kemampuan peserta didik terutama bagaimana berpikir secara kritis, berpikir kreatif termasuk dalam menyelesaikan masalah menggunakan kognitif. Dapat disimpulkan bahwa pembelajaran bahasa Arab di MTsN 2 Kota Surabaya terutama yang dilakukan oleh Guru 2 menyajikan model soal yang dapat mencapai tujuan dari HOTS yang merupakan salah satu unsur dari Kurikulum 2013.

Fitur yang tidak kalah penting yaitu CBT (Computer Based Test), guru memanfaatkan fitur ini untuk membuat soal, terutama untuk ulangan tengah semester maupun ulangan akhir semester. Namun model soal yang diberikan oleh guru MTsN 2 kota Surabaya tetap disesuaikan dengan kebutuhan peserta didik. Peneliti memperoleh data serta informasi berdasarkan wawancara yang telah dilaksanakan, pada fitur CBT guru dapat menyajikan butir soal berupa pilihan ganda, isian, dan essay beserta kunci jawabannya. Guru dapat membuat soal secara langsung melalui fitur CBT satu per satu, atau guru dapat mengambilnya dari bank soal madrasah, serta guru juga bisa mengimport soal yang sudah jadi.

\section{Kendala dan Solusi yang Dialami oleh Guru MTsN 2 Kota Surabaya dalam Mengimplementasikan E-Learning Madrasah}

Menurut pendapat guru 1, kendala yang dialami pada e-learning madrasah cukup general yaitu terdapat pada peserta didik dan teknologinya sendiri, antara lain: beberapa peserta didik mengalami susah sinyal untuk pembelajaran daring, bahkan juga terdapat peserta didik yang tidak memiliki smartphone yang digunakan untuk pembelajaran daring ini khususnya untuk mengakses aplikasi e-learning madrasah. Sejauh ini solusi yang dilakukan oleh guru 1 dari kendala diatas yakni melakukan pendekatan dengan pembelajaran luring secara bergantian terhadap peserta didik yang mengalami kendala tersebut.

Sedangkan guru 2 memberikan pendapat yang cukup spesifik terkait dengan kendala yang dialami guru pada e-learning madrasah. Yang pertama yaitu font yang digunakan pada tulisan arab

${ }^{21}$ Ade Cahyana, “Jelang AKM 2021: Mempersiapkan Higher-Order-Thinking Skills dalam Pembelajaran” (FIP- Universitas Pendidikan Indonesia, 2020), https://banpaudpnf.kemdikbud.go.id/upload/downloadcenter/Jelang\%20AKM\%202021-\%20Mempersiapkan\%20higher,\%20order,\%20thin_1591160959.pdf. 
yaitu sakkal majalla yang mana ketika materi disalin maka font tidak terbaca dengan baik. Adapun kendala lainnya yang mana guru tidak dapat memantau dengan baik siapa saja murid yang telah melihat materi dari guru di e-learning. Untuk solusi dari kendala tersebut guru 2 memilih alternatif pembelajaran melalui Whatsapp, video sebagai bahan ajar misalnya ataupun beberapa informasi ditegaskan kembali di grup whatsapp agar memaksimal pembelajaran dan meminimalisir adanya miss communication antara guru dan murid terkait pembelajaran. Namun, untuk tugas dan pengumpulannya, peserta didik tetap diminta untuk mengakses e-learning madrasah secara langsung. Sehingga whatsapp dimanfaatkan sebagai salah satu platform atau aplikasi yang membantu guru untuk melengkapi kebutuhan guru yang dianggap tidak dapat diatasi melalui elearning madrasah.

Kendala yang sama juga dirasakan oleh Guru 1 maupun Guru 2. Dimana banyak murid yang tidak online ketika guru memulai pembelajaran di e-learning, hal tersebut dikarenakan tidak adanya jadwal pembelajaran yang spesifik dan pasti sehingga pembelajaran dilaksanakan di waktu yang berbeda setiap minggunya. Menurut guru 1 hal tersebut juga terkadang mengakibatkan peserta didik tidak mengerjakan tugas yang ada, guru 1 mengatasi masalah tersebut dengan menegur peserta didik ketika diadakan pertemuan zoom. Sedangkan guru 2 seperti yang telah disebutkan di paragraf sebelumnya bahwa whatsapp digunakan semaksimal mungkin untuk menghubungi dan mengingatkan peserta didik untuk mengerjakan tugas yang telah diunggah ke $e$ learning madrasah.

\section{E. Kesimpulan}

Dari hasil data yang dikumpulkan dan dianalisis, peneliti menyimpulkan bahwa e-learning madrasah efektif untuk digunakan dalam pembelajaran bahasa Arab di MTsN 2 Kota Surabaya. Terkait dengan fitur yang disediakan oleh Kemenag dalam e-learning madrasah, guru menggunakan hampir seluruh fitur dalam pengajaran. Beberapa fitur sangat membantu guru guna meningkatkan pengetahuan serta keterampilan berbahasa peserta didik khususnya pembelajaran bahasa Arab disesuaikan dengan kebutuhan guru dalam menyajikan bahan ajar dan model soal. Pertama, dalam pembelajaran dan penilaian maharah qira'ah (keterampilan membaca), guru menyajikan bacaan melalui fitur bahan ajar dengan format PPL/PDF dan beberapa model soal, antara lain: pilihan ganda, isian, dan essay melalui fitur CBT. Kedua, dalam pembelajaran dan penilaian maharah istima' wa kalam (keterampilan menyimak dan berbicara), peserta didik diberikan video atau audio yang diberikan dalam bentuk link melalui fitur bahan ajar. Setelah mengakses video/audio tersebut, peserta didik akan diberikan beberapa soal berdasarkan dari audio/video yang didengar untuk mengukur pemahaman peserta didik yang kemudian akan dikumpulkan melalui fitur pengumpulan 
tugas. Tidak hanya itu, guru menilai kemampuan berbicara peserta didik saat melakukan video conference melalui zoom yang terjadwal dan penugasan pembuatan video sesuai KD yang diajarkan. Ketiga, dalam pembelajaran dan penilaian maharah kitabah (keterampilan menulis) guru menyajikan berbagai model soal: fill in the blank, short answer, essay melalui fitur Penilaian Pengetahuan dan juga Penilaian Keterampilan. Lalu Guru 2 juga meminta peserta didik untuk create atau membuat karangan tulisan sederhana seperti perkenalan dan lainnya sesuai dengan KD tertentu.

Mengenai kendala selain sinyal dan perangkat seperti mobile phone, kendala lain juga dialami oleh guru MTsN 2 Kota Surabaya dalam pembelajaran bahasa Arab menggunakan e-learning madrasah adalah (1) font arab yang disediakan dalam e-learning madrasah yaitu sakkal majalla yang mana ketika materi disalin maka font tidak terbaca dengan baik, (2) dikarenakan tidak adanya jadwal pembelajaran yang spesifik dan pasti, banyak murid yang tidak online ketika guru memulai pembelajaran di e-learning madrasah, (3) Murid kurang intense mengecek e-learning madrasah sehingga dikhawatirkan adanya miss communication.

Merangkum semua yang telah peneliti jabarkan, peneliti mengusulkan beberapa saran terkait dengan kendala yang ada dan tentunya diharapkan dapat membantu guru terkait maupun tenaga pendidik lainnya di era pandemi ini. Yang pertama, sekolah dan guru seharusnya memberikan jadwal yang pasti dengan waktu yang spesifik setidaknya dalam seminggu kedepan, sehingga peserta didik dapat bersiap-siap untuk memulai pembelajaran, mengecek e-learning madrasah, serta bergabung dalam diskusi maupun kegiatan pembelajaran lainnya. Yang kedua, guna menghindari kejenuhan pembelajaran daring pada peserta didik, akan lebih baik jika guru sesekali memberikan permainan, kuis ataupun model pembelajaran lainnya yang menyenangkan, tidak hanya itu bahan ajar dan model soal juga dapat didesain sekreatif dan variatif mungkin, seperti video animasi, komik, puzzle, dll. Yang ketiga, seperti yang telah dilakukan Guru 2, platform atau aplikasi lainnya dapat digunakan untuk menyempurnakan kekurangan dan mengatasi kendala yang ada, sehingga guru dapat berkomunikasi lebih mudah dengan murid, dan pembelajaran berjalan dengan efisien. Peneliti juga memberikan saran untuk peneliti selanjutnya agar melakukan penelitian di semester genap agar peneliti dapat menganalisa secara langsung model soal, penugasan, penilaian dan lainnya. Juga dikarenakan PPKM ini peneliti mungkin kurang maksimal dalam mengumpulkan data penelitian, diharapkan peneliti selanjutnya dengan kondisi yang lebih baik dapat memaksimalkan penelitiannya. 


\section{Daftar Rujukan}

Cahyana, Ade. (2020). "Jelang AKM 2021: Mempersiapkan Higher-Order-Thinking Skills dalam Pembelajaran." $\quad$ FIP- Universitas Pendidikan Indonesia. https://banpaudpnf.kemdikbud.go.id/upload/download-center/Jelang\%20AKM\%202021\%20Mempersiapkan\%20higher,\%20order,\%20thin_1591160959.pdf.

Creswell, John W. (2012). Educational research: Planning, conducting, and evaluating quantitative. 4 ed. Baston, MA: Pearson,

Fitriani, Siti Nurul, Syarifah Syarifah, dan Ali Susanto. (2020). "Pembelajaran Bahasa Arab Interaktif Melalui Media E-Learning Madrasah di MTsN 1 Kota Malang." Tarbiyatuna: Jurnal Pendidikan Ilmiah 5, no. 2: 159-82.

Hariani, Pipit Putri, dan Sri Ngayomi Yudha Wastuti. (2020). "Pemanfaatan e-learning pada pembelajaran jarak jauh di masa pandemi covid-19." Biblio Couns: Jurnal Kajian Konseling dan Pendidikan 3, no. 2: 41-49.

Hikmah, Shofaul. (2020). "Pemanfaatan e-learning Madrasah dalam Pelaksanaan Pembelajaran Jarak Jauh Masa Pandemi di MIN 1 Rembang." Edutrained J. Pendidik. dan Pelatih 4, no. 2: 73-85.

Kemenag. (2021). “E-Learning Madrasah Official.” https://elearning.kemenag.go.id/. Diakses 28 Desember 2021. https://elearning.kemenag.go.id/.

Khomsah, Ahmad Fadilah, dan Muassomah Muassomah. (2021). "Penerapan E-learning dalam Pembelajaran Bahasa Arab di Masa Pandemi." Tarbiyatuna: Jurnal Pendidikan Ilmiah 6, no. 1: $1-14$.

Kosim, Nanang, Imam Turmudi, Novy Maryani, dan Abdul Hadi. (2020). "Pembelajaran bahasa Arab melalui daring: Problematika, solusi dan harapan.” Work From Home.

Kuswanto, Joko, dan Ferri Radiansah. (2018). "Media Pembelajaran Berbasis Android Pada Mata Pelajaran Sistem Operasi Jaringan Kelas XI." Jurnal Media Infotama 14, no. 1.

Meilwansyah, Teddy. “Pembelajaran di Masa Pandemi Covid-19." Diakses 28 Desember 2021. https://diknas.okukab.go.id/berita/detail/pembelajaran-di-masa-pandemi-covid19.

Redhana, I. Wayan. (2019). "Mengembangkan keterampilan abad ke-21 dalam pembelajaran kimia." Jurnal Inovasi Pendidikan Kimia 13, no. 1.

Riqza, Meidiana Sahara, dan M. Muassomah. (2020).“Media Sosial untuk Pembelajaran Bahasa Arab pada Masa Pandemi: Kajian Kualitatif Penggunaan WhatsApp pada Sekolah Dasar di Indonesia." Alsina: Journal of Arabic Studies 2, no. 1: 71-94.

Setyawan, Cahya Edi, dan Khairul Anwar. (2020). "Peran Bahasa Arab Dalam Pendidikan Islam Sebagai Urgensitas Menghadapi Revolusi Industri 4.0." Lahjah Arabiyah: Jurnal Bahasa Arab Dan Pendidikan Bahasa Arab 1, no. 1: 11-19. 
Hamdatul Musyarrofah, Hilma Nailis Syarifiyah, Muhammad Anis Bachtiar

Sulistio, Andi. (2021). "Peningkatan Prestasi Belajar Bahasa Inggris Melalui Pembelajaran Jarak Jauh (PJJ) dalam Penerapan Pembelajaran Sinkron dan Asinkron Melalui Google Classroom, Google Meet Dan Aplikasi E-Learning." SECONDARY: Jurnal Inovasi Pendidikan Menengah 1, no. 2: 63-69. 